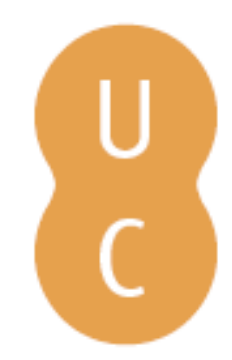

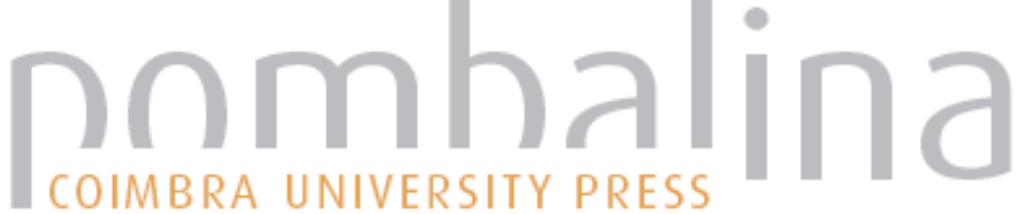

\section{A figura de Sócrates como amante e guia nos Diálogos de Platão}

Autor(es): $\quad$ Motta, Guilherme Domingues da

Publicado por: Imprensa da Universidade de Coimbra; Annablume

URL

persistente: URI:http://hdl.handle.net/10316.2/40848

DOI: $\quad$ DOl:https://doi.org/10.14195/978-989-26-1288-1_3

Accessed : $\quad$ 26-Apr-2023 08:54:58

A navegação consulta e descarregamento dos títulos inseridos nas Bibliotecas Digitais UC Digitalis, UC Pombalina e UC Impactum, pressupõem a aceitação plena e sem reservas dos Termos e Condições de Uso destas Bibliotecas Digitais, disponíveis em https://digitalis.uc.pt/pt-pt/termos.

Conforme exposto nos referidos Termos e Condições de Uso, o descarregamento de títulos de acesso restrito requer uma licença válida de autorização devendo o utilizador aceder ao(s) documento(s) a partir de um endereço de IP da instituição detentora da supramencionada licença.

Ao utilizador é apenas permitido o descarregamento para uso pessoal, pelo que o emprego do(s) título(s) descarregado(s) para outro fim, designadamente comercial, carece de autorização do respetivo autor ou editor da obra.

Na medida em que todas as obras da UC Digitalis se encontram protegidas pelo Código do Direito de Autor e Direitos Conexos e demais legislação aplicável, toda a cópia, parcial ou total, deste documento, nos casos em que é legalmente admitida, deverá conter ou fazer-se acompanhar por este aviso. 


\section{Cosmópolis}

\section{mobilidades culturais às origens do pensamento antigo}

Gabriele Cornelli, Maria do Céu Fialho e Delfim Leão

\section{(coords.)}

IMPRENSA DA UNIVERSIDADE DE COIMBRA 


\title{
A figura de Sócrates como amante e guia nos Diálogos de Platão
}

[Socrates as lover and guide in Plato's Dialogues] ${ }^{1}$

\author{
Guilherme Domingues da Motta (guilherme.motta@ucp.br) \\ Universidade Católica de Petrópolis/PUC-Rio
}

Resumo: Compreender o Sócrates dos Diálogos platônicos como um homem animado por eros implica em reconhecer duas dimensões dessa personagem: em primeiro lugar, trata-se de um homem que passou por uma conversão, fato que o transformou num apaixonado pela mais alta forma de conhecimento; em segundo lugar, é um homem que, após tal conversão, tornou-se, como diz o Banquete, "fecundo na alma", ou seja, alguém que experimenta urgência em transmitir seus conhecimentos quando encontra um receptáculo adequado. O "fecundo na alma" representa, em boa parte do Banquete, o homem que é capaz de guiar os jovens no caminho da aquisição da virtude cívica e que se engaja numa relação pederástica com eles, de modo que também a personagem Sócrates estabelece relações pederásticas, as quais, todavia, são de natureza singularíssima. Se, por um lado, Sócrates é "grávido" da virtude "epistêmica", a qual vai além da virtude cívica tradicional, por outro lado, Sócrates não se interessa pelo corpo dos jovens que guia, nem deles espera favores sexuais. Uma interpretação unitária desta personagem através dos diálogos permitirá sustentar que Sócrates não é movido por atração sexual pelos jovens que guia, ainda que uma abordagem superficial de certas passagens possa sugerir o contrário.

Palavras-chave: Sócrates, Platão, eros, amante, guia

Авstract: In order to understand the Socrates of Plato's Dialogues as someone moved by eros one must recognize two dimensions of this character: firstly, that he is a man who has experienced a conversion which has turned him into a lover of the highest form of knowledge; secondly, that he is a man who by this conversion became, as the Symposium puts it, "fruitful in the soul", i.e., someone who feels the urgent need to communicate his knowledge once he has found the right receptacle. Being "fruitful in the soul" represents, in the largest part of the Symposium, a person who is able to lead young men to the acquisition of civic virtue, engaging in pederastic relationships with them; being so, Socrates too establishes pederastic relations with young men, but one of a very special kind. On the one hand, he is "pregnant" with "epistemic virtue" and feels the need to pass it on. On the other hand, he is not interested in the body of young men, nor is he expecting sexual favours in return. A unitary interpretation of Socrates' character through the Dialogues will show that He is not driven by sexual attraction for the young men he longs to guide, as a superficial approach might suggest.

Keywords: Socrates, Plato, eros, lover, guide

${ }^{1}$ Texto redigido no âmbito de estágio pós-doutoral com apoio da CAPES 
Como destacado por Ruby Blondel, o Banquete de Platão contém várias referências a percursos ou jornadas, tais como a de Apolodoro em companhia de Glaucon e a de Sócrates em companhia de Aristodemo rumo à casa de Agatão, as quais antecipariam a jornada simbólica descrita na célebre "escada do amor", no fim do discurso de Diotima. Em todas essas jornadas se manifesta um sentido colaborativo entre os participantes, e especificamente na "escada do amor" é fundamental o papel do guia ${ }^{2}$.

A ideia de um percurso que visa a um fim e que é efetuado na companhia de alguém capaz de desempenhar o papel de guia se encaixa perfeitamente no modelo de pederastia vigente em algumas poleis gregas. Seria, pois, natural que alguém tão interessado como Platão na questão da educação tivesse algo a dizer sobre a pederastia; de fato, em muitos diálogos ela é direta ou indiretamente tratada.

Embora Platão pareça opor-se à prática tradicional da pederastia tanto na República ${ }^{3}$ quanto nas $L_{e i s^{4}}$, sabe-se que nos diálogos Sócrates é frequentemente descrito por outras personagens como alguém que procura acercar-se de belos jovens, chegando mesmo a ser referido como alguém que os "caça”. por exemplo, diz Alcibíades: Bem vedes como Sócrates tem a paixão dos belos adolescentes e como fica fora de si na presença deles, sem deixar de rondá-los o dia todo 6 .

Eu poderia multiplicar aqui as referências a passagens em que se sugere ou que Sócrates tem Alcibíades como amado ou que vive a procura de belos jovens ${ }^{7}$. Nesse respeito é frequentemente lembrada uma passagem do Cármides. Narra-se neste diálogo que Sócrates, depois de um prolongado período de ausência de Atenas por estar a serviço da cidade na guerra, deseja inteirar-se sobre como vão as coisas no que diz respeito à filosofia, e se algum jovem se distingue pela sabedoria, pela beleza ou por ambas 8 . Sobre a beleza dos jovens, Crítias informa-lhe que aquele que é considerado o mais belo já vem chegando, Cármides9. Quando este entra em cena, seguido por inúmeros admiradores, causa um grande reboliço não só entre eles, mas também entre os demais presentes, pois todos tentam ficar o mais próximo possível dele. A passagem merece ser citada:

(...) Sua chegada foi causa de hilaridade geral; sentados como estávamos cada um de per si começou a empurrar o vizinho, para abrir lugar ao seu lado para Cármides, de forma que dos dois da extremidade, um teve de levantar-se, e o outro derrubamo-lo de viés. Dirigindo-se para o nosso lado, Cármides sentou-se entre

\footnotetext{
${ }^{2}$ Ver: Blondel 2006: 147-152.

${ }^{3}$ Cf. Pl. Resp. 403a-c.

${ }^{4}$ Cf. P1. Leg. 836b-841d.

${ }^{5}$ P1. Prot. 309a.

${ }^{6}$ P1. Symp. 216d. Nunes 2001a: 84.

${ }^{7}$ P1. Symp. 213c-d; P1. Lys. 206a; P1. Men. 76b-c; P1. Grg. 481d; P1. Grg. 482a-b.

${ }^{8} \mathrm{Pl}$. Chrm. 153d.

${ }^{9}$ Pl. Chrm. 154a.
} 
mim e Crítias. Nesse instante, amigos, fiquei atrapalhado e me vi abandonado da confiança habitual, com que contava para conversar naturalmente com ele. $\mathrm{E}$ depois de lhe haver dito Crítias que eu era o que conhecia o remédio, olhou para mim por maneira indescritível, como quem dispunha a interrogar-me, vindo a formar um círculo em torno de nós as demais pessoas que se achavam na palestra. Nesse momento, meu grande amigo, olhei para dentro das vestes de Cármides e me senti abrasado e fora de mim, tendo, então compreendido quão sábio fora Cídias em matéria de amor, por haver aconselhado alguém, com referência a um belo rapaz: "Cuidado deve ter a corsa tímida; do leão não se aproxime, para presa dele não vir a ser". Eu, de mim, já me julgava nas garras de semelhante fera. Não obstante, como me houvesse ele perguntado se eu conhecia remédio para dor de cabeça, bem ou mal respondi que conhecia ${ }^{10}$.

Esta passagem pode ser considerada por muitos como um testemunho da humanidade do Sócrates histórico ou mesmo da personagem dos diálogos, a qual também estaria sujeita a se sentir atraída fisicamente por um belo jovem, como, de resto, seria perfeitamente aceitável na Atenas do seu tempo. Porém, eu gostaria de propor outra via interpretativa, que, creio, é capaz de manter a unidade e a coerência da personagem Sócrates ${ }^{11}$ ao longo dos diálogos, nomeadamente, a interpretação segundo a qual a beleza física dos jovens dos quais Sócrates se aproxima não tem qualquer importância para ele.

Note-se que Platão, no Banquete, diálogo em que faz Alcibíades afirmar que Sócrates tem paixão pelos belos adolescentes e que fica a rondá-los, põe na boca do mesmo Alcibíades que Sócrates não se preocupa o minimo com a beleza de ninguém; chega mesmo a desprezá-la por maneira incrivel; o mesmo acontece com a riqueza e com todas essas vantagens tão apreciadas pelo vulgo' ${ }^{12}$.

Alcibíades descreve, ainda no Banquete, a decepção que teve ao constatar que sua própria beleza não teve sobre Sócrates o efeito que supusera ${ }^{13} . \mathrm{Na}$ narração deste episódio, Alcibíades afirma que, por considerar Sócrates dentre seus apaixonados ${ }^{14}$, e o único digno dele, declarou-se disposto a ceder aos desejos eróticos que aquele supostamente nutriria por si. Tendo criado, então, a ocasião propícia, comunicou ao seu suposto apaixonado que cederia aos seus desejos (tudo isso dentro da mais rigorosa ética que rege a relação eromenos-erastes ${ }^{15}$, não constituindo, pois, vergonha nenhuma para os dois). Tendo feito isso, deitou-se

${ }^{10}$ Pl. Chrm. 155c-e. Nunes 2007a: 122.

${ }^{11}$ Em nenhum momento ao longo desse texto tenho a pretensão de referir-me ao Sócrates histórico.

${ }^{12}$ P1. Symp. 216d-e. Nunes 2001a: 84.

${ }^{13}$ P1. Symp. 217a-219d.

${ }_{14}$ Pl. Symp. 218c.

15 Para a descrição de uma relação nestes moldes: Dover 1994; e o próprio discurso de Pausânias em P1. Symp. 180c-185c. 
nu ao seu lado e abraçou-o, não conseguindo, entretanto, despertar o efeito esperado em Sócrates, que dormiu ao seu lado como um pai ou um irmão ${ }^{16}$.

Como já deve estar claro, não é tarefa fácil harmonizar todas essas passagens: ora ficamos com a impressão de que Sócrates incluía-se no quadro tradicional das relações pederásticas em voga na Atenas da época ${ }^{17}$, ora, como no episódio do Banquete há pouco referido, tal imagem fica, no mínimo, em xeque.

É certo que renunciar a ver em Sócrates, personagem dos diálogos, um homem "erótico" e "apaixonado pelos belos jovens" seria um contrassenso e empobreceria uma figura tão genialmente construída por Platão. Porém, é preciso procurar entender o que levaria essa personagem, amante de belos jovens, a renunciar aos favores sexuais do belo Alcibíades, mesmo estando num contexto de todo propício.

Talvez haja um sentido bastante específico em que Sócrates possa ser considerado "erótico" e amante de belos jovens, sentido que deva ser relacionado com a emergência que nele ocorreu, depois de um longo percurso, do eros filosófico. Tal forma específica de eros representaria o desejo pela mais alta forma de conhecimento, o conhecimento das Formas, e foi descrita por Charles Kahn como uma manifestação específica do desejo racional pelo bem, cuja sede é o elemento racional da alma ${ }^{18}$.

Já procurei mostrar num outro texto ${ }^{19}$ que se o eros filosófico é desejo pela forma mais alta do conhecimento, o conhecimento das Formas, ele dependeria do desenvolvimento prévio da capacidade de reconhecer, de um lado, a existência desse tipo de objeto e, de outro, o valor que há em conhecê-lo. Mas ainda há, como quero aqui propor, uma segunda dimensão de eros filosófico, que consiste no urgente desejo de transmitir o conhecimento filosófico ou, o que redunda no mesmo, o desejo de estimular o desenvolvimento da capacidade (dynamis) que se adquiriu.

A aquisição da dynamis que torna possível o conhecimento supremo é longamente tratada na República, obra que se ocupa explicitamente do percurso a ser trilhado pelo aspirante a filósofo ${ }^{20}$. No Banquete tudo é muito mais sintético, até mesmo elíptico ${ }^{21}$, porém na passagem conhecida como "escada do amor" pode-se dizer que o que permite que o amante faça o percurso ascensional é a aquisição dessa dynamis. Elemento comum aos dois textos referidos, bem como a outros diálogos de Platão, é que o momento da aquisição dessa capacidade ( $d y$ namis) é também momento de uma "conversão", motivo pelo qual é tão comum

${ }^{16}$ Cf. P1. Symp. Banquete, 216e-219d.

${ }^{17}$ Ver passos citados na nota 4, supra.

${ }^{18}$ Kahn 1996: 278.

${ }^{19}$ Motta 2013.

${ }^{20}$ Para uma descrição da educação superior proposta para o aspirante a filósofo na República, ver P1. Resp. 521a-535a.

${ }^{21}$ Toda referência a esse percurso de formação estaria sintetizado na "escada do amor" que começa com a menção de ter sido o "iniciado" bem guiado. Ora, o que ocorre em seguida, pode-se dizer, é que este dá mostras de ter se tornado um dialético. Cf. Pl. Symp. 210a-212a. 
o uso de linguagem religiosa quando dela se trata nos diálogos platônicos ${ }^{22}$. No Banquete tal conversão pode ser entendida como consequência dos ensinamentos de Diotima, e toda a linguagem iniciática aqui utilizada reforçaria o caráter quase religioso desse encontro. Na República, a conversão do intelecto que representa a aquisição da dynamis filosófica é explicitamente tratada, como se verá adiante.

Uma vez adquirida essa dynamis, síntese de natureza e educação ${ }^{23}$, o filósofo torna-se um homem erótico, no sentido de ser tomado por eros filosófico e de não conseguir mais ver as coisas sob outra ótica que não seja a filosófica; este passa, então, a abordar tudo como um verdadeiro dialético.

É por isso que, no Banquete, quando Diotima introduz os chamados "grandes mistérios", afirma ela que aquele que foi bem guiado começará por amar um só corpo, mas, então, compreenderá que a beleza desse corpo é cognata daquela que há em outros corpos belos ${ }^{24}$. Isso significa que aquilo que está em jogo aqui quando se usa o verbo "amar" é o amor filosófico, ou seja, estar de tal forma convertido à filosofia que o único olhar possível seja o dialético, aquele que busca o uno no múltiplo.

Na República, há uma referência textual a essa "conversão" que coincide com a aquisição da dynamis filosófica; Sócrates afirma:

A presente discussão indica a existência dessa faculdade (dynamin) na alma e de um órgão pelo qual aprende; como um olho que não fosse possível voltar das trevas para a luz, senão juntamente com todo o corpo, do mesmo modo esse órgão deve ser desviado, juntamente com a alma toda, das coisas que se alteram, até ser capaz de suportar a contemplação do Ser e da parte mais brilhante do Ser. A isso chamamos o bem. Ou não $0^{25}$ ?

Diante da resposta afirmativa de Gláucon à sua pergunta, continua:

A educação seria, por conseguinte, a arte desse desejo, a maneira mais fácil e mais eficaz de fazer dar a volta a esse órgão, não a de o fazer obter a visão, pois já a tem, mas, uma vez que não está na posição correta e não olha para onde deve, dar-lhe os meios para isso ${ }^{26}$.

Sócrates refere-se à pretensão de alguns de introduzir ciência (episteme) numa alma na qual ela não exista. O que fica claro nas passagens citadas é que ele considera a posse da episteme algo que depende de uma dynamis, a qual envolve um órgão próprio, que, no contexto da República, sabe-se ser o intelecto.

\footnotetext{
${ }^{22}$ Sobre esse ponto ver Kahn 1996: 273.

${ }^{23}$ Sobre esse ponto ver Motta 2014.

${ }^{24}$ Pl. Symp. 210b.

${ }^{25}$ P1. Resp. 518c-d. Pereira 1987: 320-321.

${ }^{26}$ Pl. Resp. 518c-d. Pereira 1987: 320-321.
} 
Sócrates, personagem dos diálogos, foi moldado para que o leitor perceba que ele já passou por uma conversão, que o tornou, no mínimo, um homem extraordinário, atípico. Assim, qualquer tentativa de interpretação dessa personagem que não leve em conta a radicalidade de sua conversão e seu caráter atípico estará fadada ao erro. Isso vale, obviamente, para a questão "erótica", que, no seu caso, diz respeito sempre a essa forma específica e atípica de eros, que se pode chamar de eros filosófico.

No Banquete o eros filosófico é abordado no contexto do que se chama "os mistérios maiores" ${ }^{27}$, ou seja, o trecho da obra que contém a descrição feita por Diotima da ascensão em direção à Forma da Beleza e que corresponde à "escada do amor". Essa passagem é precedida pelos chamados "mistérios menores", que incluem os esclarecimentos prévios que Diotima dá a Sócrates sobre a natureza de eros. É importante para a tese aqui analisada começar por um exame dos "mistérios menores".

Em seus esclarecimentos prévios, Diotima estabelece que eros, por ser desejo de possuir o bem, sempre é desejo de imortalidade, abrindo assim caminho para a afirmação de que a forma pela qual os amantes buscam atingir a imortalidade é procriar no belo (en kaloi) ${ }^{28}$, seja por meio do corpo, seja por meio da alma.

Em seguida, a sacerdotisa divide os homens em duas classes: os fecundos (kyousin $^{29}$ no corpo e os que o são na alma ${ }^{30}$. Aqueles fecundos no corpo geram filhos, e, obviamente, tem de fazê-lo com uma mulher. Os fecundos na alma produzirão belas obras ou procurarão belos jovens para neles incutir a virtude cívica da qual estão "grávidos", através de belos discursos sobre a virtude, as leis e as instituições ${ }^{31}$.

No contexto dos "mistérios menores", a geração dos fecundos na alma, como é descrita por Diotima, não parece, portanto, afastar-se da concepção apresentada no mesmo diálogo por Pausânias acerca das relações pederásticas regidas por eros urânio, uma vez que tanto num caso como no outro está em foco a transmissão da virtude cívica ${ }^{32}$. Porém, mesmo num contexto assim, o jovem

${ }^{27}$ Cf. P1. Symp. 209e-212e.

${ }^{28}$ P1. Symp. $206 \mathrm{~b} 10$.

${ }^{29}$ Note-se que Sócrates, ao introduzir o termo que muitos traduzem como fecundo ou fértil, utiliza kyousin, forma do verbo kyeo. Angela Hobbs reconhece que o termo no Banquete pode significar, como querem alguns, o estado de excitação masculina e a ejaculação. Porém, essa autora não exclui que a escolha do termo por Platão coloca o leitor diante de uma imagem que evoca tanto a mulher grávida, que tem o corpo inchado com a gravidez, quanto um "homem grávido" que tem a mente, e não o corpo, inchada pela "gravidez". Cf. Hoobs 2006: 263-265. De todo modo, considerando-se que há um momento no qual a criança gestada por uma mulher se encontra pronta e tem de vir à luz, a analogia com o fecundo na alma parece perfeita, uma vez que este também, quando "grávido" de conhecimento, tem urgência em trazer à luz o que carrega quando se encontra diante do belo. Note-se ainda que nas próprias palavras do Banquete o "não gerar", no caso daquele que está pronto para tal, produz o "incômodo fardo da semente" (206d) e o encontro com a beleza o "alivia do grande sofrimento da geração" (206e).

${ }^{30}$ Cf. P1. Symp. 206a-209e.

${ }^{31}$ P1. Symp. 208e-209e.

32 Para o discurso de Pausânias, ver P1. Symp. 180c-185c. 
educando deve, segundo Pausânias, conceder favores sexuais ao seu guia, em troca de seu aprimoramento e aquisição da virtude cívica dele decorrente ${ }^{33}$.

Assim, embora a concepção de Pausânias possa superficialmente assemelhar-se com a concepção de Diotima nos "mistérios menores", já se apresenta uma diferença notável entre a concepção da sacerdotisa do que seja uma relação entre um amante "grávido" da virtude cívica com seu amado e a concepção de Pausânias acerca das relações pederásticas urânias: $\mathrm{Na}$ descrição de Diotima, não consta qualquer referência a favores sexuais ${ }^{34}$. Essa diferença anuncia uma nova concepção do que seja uma relação desejável entre amante e amado, tanto em vista da virtude cívica, quanto em vista da "virtude epistêmica" que será abordada mais tarde no diálogo, nos "mistérios maiores". Porém, essa primeira inflexão já é relevante para lançar alguma luz sobre a figura de Sócrates como amante e guia de belos jovens ao longo dos diálogos.

Para compreender essa figura se faz necessário, porém, aprofundar a noção de eros apresentada por Diotima, assim como sua concepção de "fecundidade" que implica num desejo de gerar no belo. Sobre esse desejo, diz Diotima:

Todos os homens são fecundos [kyousin], Sócrates, ou segundo o corpo, ou segundo o espírito, e quando atingimos determinada idade, nossa natureza tem vontade de procriar. Ora, procriar no feio não é possível, terá que ser no belo [en kaloi]. A união do homem e da mulher é geração, obra divina, participando, assim, da imortalidade o ser mortal, pela concepção e pela geração. Mas é impossível que isso se realize no que é discordante; tudo o que é feio está em discordância com o divino, ao passo que o que é belo está em consonância com ele. Logo a Beleza é parteira da geração; é Parca e Ilitiia a um só tempo. Por esse motivo, sempre que o poder fecundante se aproxima do que é belo, fica jovial e expansivo no seu regozijo, e concebe e procria. Porém, quando se trata de algo feio, retrai-se aflito e triste, recolhe-se em si mesmo e afasta-se sem gerar, levando consigo o fardo incômodo da semente. É o que explica o alvoroço inefável do ser fecundo e transbordante da seiva diante da beleza, pois esta o alivia do grande sofrimento da geração ${ }^{35}$.

Se se interpretasse, como fazem muitos, que Diotima usa nessa passagem o termo "belo" contido na expressão "gerar no belo" (en kaloi) ${ }^{36}$ no sentido de beleza física

${ }^{33}$ Sobre a insistência de Pausânias na concessão de favores sexuais ao erastes por parte do eromenos na relação urânia, ver Pl. Symp. 182a2-3, 182b1-3, 182c5-d1, 183d6-8, 184b5-6, 184c7-d3, 184c6-a5, 185a5-b5. Passagens compiladas por Alieva 2013: 154. Sobre esse ponto, ver também Brisson 2006.

${ }^{34}$ Sobre o fato de que uma pederastia sexualizada não é abordada por Diotima, ver Corrigan 2006: 145.

35 P1. Symp. 206 c-e. Nunes 2001a: 69-70.

${ }^{36}$ P1. Symp. 206c. Nunes 2001a: 69. O problema para o intérprete da questão reside não apenas nesta passagem, mas igualmente na interpretação de en kaloi em 206b, de en toi kaloi em 206e, e de to kalon en hoi em 209b. Para uma possível solução para este problema, ver nota 
do objeto no qual se gera, seguir-se-ia o absurdo de se afirmar que um homem em idade de procriar procurará uma mulher bonita para procriar, e que seria impossível fazê-lo com uma mulher feia. $\mathrm{O}$ absurdo de tal interpretação agrava-se ainda mais se se entende que Diotima caracteriza eros como um desejo universal de imortalidade (que se realiza através da procriação no belo), estando presente em todos os animais:

Sócrates, qual te parece ser a causa desse amor e desse desejo? Ainda não observaste em que estado de braveza ficam os animais no tempo de procriar, os que voam e os que marcham, como que padecendo dessa loucura amorosa, primeiro quando se unem, depois para criar os filhos, e como até mesmo os mais fracos se atrevem a defendê-los contra os mais fortes e a morrerem por eles, e como suportam os horrores da fome e tudo o mais, só para alimentá- $\operatorname{los}^{37}$ ?

Se eros é desejo de imortalidade e o modo de atingi-la é a procriação no belo, e se, por outro lado, é também um desejo universal, que atinge até as bestas, como interpretar o caso de, por exemplo, um cavalo fecundo (obviamente, no corpo) que procura procriar no belo?

Entendo que "belo" aqui deva ser entendido como "lugar apropriado" 38 , ou, de modo derivado, "terreno fértil". Uma égua bela, nesse sentido, seria fundamentalmente a égua saudável, que dê sinais de ser um bom receptáculo para carregar a herança genética do macho e que, obviamente, esteja no cio. Esse tipo de "beleza" pode manifestar-se em marcas exteriores, tais como certa aparência, cheiro, ou qualquer outro aspecto sensível que denuncie esse tipo de "estado de maturidade", de "adequação à função" ou de "aptidão" para receber a semente fecundante.

Ora, o mesmo valeria para os seres humanos: quando, estando na idade apropriada, diz-se que um homem procura uma mulher para "procriar no belo", o que não seria possível fazer na fealdade, isto só pode significar que procura uma mulher madura, fértil e apta a gerar um filho; apta, portanto, para ser um bom receptáculo para a semente fecundante.

Essa mesma interpretação da expressão "en kaloi" aplicada, então, aos fecundos na alma abre caminho para que se entenda que Sócrates, um fecundo na alma que vive à caça de belos jovens, não tem em vista a beleza física destes. Note-se o que diz Diotima sobre os fecundos na alma:

Os fecundos na alma... Sim, porque há também pessoas, me falou, cuja força fecundante reside na alma, muito mais ativa do que a do corpo, com relação às

37 deste trabalho.

${ }^{37}$ Pl. Symp. 207a-b. Nunes 2001a: p.70-71

38 Proponho que a única interpretação capaz de dar conta satisfatoriamente do texto platônico consiste em compreender "o belo" - to kalon - nas passagens mencionadas (cf. nota 35) no sentido de "lugar propício" ou "lugar adequado", estando a expressão "lugar" implícita, como, de resto, nos facultam Liddell-Scott 1940: 870; e Bailly 2000: 1012. 
coisas que convém à alma conceber e procriar. E que lhes convém conceber? A sabedoria e as demais virtudes de que, precisamente, os poetas são pais, e os artistas dotados de espírito inventivo. A porção mais importante e bela da sabedoria, continuou, é a referente ao governo das cidades e à organização da família, o que recebeu o nome de prudência e justiça. Quando a alma de um desses homens divinos encerra essa virtude fecundante e, na idade própria, sente desejos de fecundar e procriar, põe-se também, segundo creio, a procurar por toda parte o belo [to kalon] para nele procriar, o que jamais poderia dar-se na fealdade ${ }^{39}$.

Como fica evidente no trecho citado, a procriação também no caso do fecundo na alma tem de dar-se no belo, não podendo ocorrer na fealdade. Também aqui a beleza só pode significar "terreno fértil” para os ensinamentos, sejam morais ou "epistêmicos", dos quais o amante ou guia está "grávido" e necessita urgentemente transmitir. Mas quando se trata de reconhecer a aptidão para receber ensinamentos como os de Sócrates ou de Diotima, o que bem pode ser caracterizado como "beleza da alma", não há traço físico que possa denunciar essa feliz condição.

Note-se, a propósito, que Sócrates é um homem bastante feio. Ainda assim, Platão fez dele o protótipo da "bela alma”, se se entender que a expressão significa a boa natureza ${ }^{40}$, o terreno fértil para ser fecundado pelo ensinamento da amante, amante que, no caso do Banquete, é a própria Diotima. Estando "grávida", Diotima reconhece a "beleza da alma” de Sócrates e, por isso, dedica-se a ele ${ }^{41}$.

Teeteto, personagem do diálogo homônimo, seria outro "feio" de quem também se pode afirmar que possui uma bela alma no sentido acima proposto ${ }^{42}$.

${ }^{39}$ P1. Symp. 208e-209b. Nunes 2001a: 73.

${ }^{40}$ Note-se que na República a educação dos futuros filósofos depende fundamentalmente de uma natureza apropriada, a descoberta da qual só vem a ocorrer depois de um longo período de observação e de testes. Os jovens que na Kallipolis serão destinados à educação superior nas matemáticas e na dialética tem de corresponder, proponho eu, aos que são chamados de "belos jovens" ao longo dos diálogos. Estes "belos jovens" são aqueles que despertam uma das dimensões do eros filosófico em Sócrates, a saber, a dimensão da urgência em transmitir sua própria dynamis filosófica, a qual parece emergir simultaneamente ao intenso desejo de buscar o conhecimento filosófico. Sobre o efeito da eventual beleza física desses jovens em Sócrates, como no caso do Cármides, voltarei mais adiante.

${ }^{41}$ Cf. P1. Symp. 207c. Note-se aqui que a relação de Sócrates com Diotima não se resumiu a um encontro.

42 Além de não ser belo, não pode ser por acaso que Teeteto se parece com o próprio Sócrates, como também não é por acaso que o elenco de suas qualidades seja praticamente o mesmo que se diz na República que deve ter, por natureza, o jovem aspirante à educação filosófica. É esse tipo de natureza que venho propondo aqui que deve ser identificada como o que caracteriza um "belo jovem", ou, dito de outro modo, o que denuncia a posse de uma "bela alma". Cf. Pl. Tht. 143e-144b. Sobre as características que se atribuem aos que receberão a educação superior citadas em P1. Resp. 462c7-8, 503c, 535b-c. 
É essa beleza que Platão quer fazer ver ao leitor que atrai Sócrates, e faz dele um caçador de belos jovens.

Não é por outro motivo, portanto, que a segunda dimensão de eros filosófico, a urgência de transmitir o conhecimento mais alto, urgência que move Sócrates, só pode aparecer na "escada do amor" no seu segundo "degrau", quando tudo o que importa é a beleza da alma ${ }^{43}$.

Assim, interpreto como eminentemente irônica a afirmação de Diotima que segue imediatamente a última passagem citada, acerca dos fecundos na alma:

Essa a razão de deleitar-se muito mais com os corpos belos do que com os feios, por querer procriar; e se coincide encontrar uma alma bela, generosa e bem nascida, alegra-se sobremodo com essa dupla beleza, a do corpo e a da alma $^{44}$.

A consequência disso tudo é que se Sócrates pode ser considerado um homem fecundo na alma, todas as referências à prática de Sócrates de "caçar" belos jovens devem ser entendidas como a procura do terreno fértil para seus ensinamentos, e "belo jovem" só pode ser entendido como alguém que possui uma "bela alma", no sentido de terreno fértil. O fato de que alguns desses jovens sejam também fisicamente belos não passa de um jogo de Platão com o vocabulário do desejo e com as práticas pederásticas endossadas por seus contemporâneos.

Deve-se também ressaltar a esse propósito que esses jovens nunca são apenas belos fisicamente, mas sempre promissores e dotados de outras qualidades que podem levar Sócrates a pelo menos supor que são "terreno fértil" para seus ensinamentos ${ }^{45}$. Isso pode bem indicar que o fato de Sócrates "caçá-los" não tem, necessariamente, nada a ver com sua beleza física, e que apostar nessa interpretação pode ser uma aposta apressada e de todo fadada ao erro.

${ }^{43}$ Tema a que voltarei.

${ }^{44}$ P1. Symp. 209b. Ora, se se sustenta o argumento anterior, então não faria sentido retroceder e aceitar que, para a aquisição de conhecimento, a beleza do corpo possa ser vantajosa. Isso não faz sentido qualquer que seja o contexto, pois até mesmo para os fecundos no corpo já se defendeu anteriormente que procriar no belo não depende de beleza física. Ademais, o restante do Banquete parece deixar bem claro que a beleza física é irrelevante no que diz respeito à "fecundação da virtude": [...] Daí por diante, terá que achar que a beleza da alma é muito mais preciosa que a do corpo, de forma que uma alma de dotes excepcionais, até mesmo num corpo carecente de viço, é quanto lhe basta para amá-la e dela cuidar [...] (Pl. Symp. 210b-c. Nunes 2001a: 75). O trecho, portanto, tem de ser irônico, e tal ironia bem poderia estar dirigida a Pausânias, o qual, malgrado afirme ser a beleza da alma a única que importa numa relação pederástica urânia, tem como amado o belo Agatão. Ademais, dizer que numa relação que envolve desejo sexual a beleza não deve contar, parece hipócrita da parte de Pausânias. Seu discurso sobre a não necessidade da beleza física seria muito mais verossímil se não insistisse tanto no aspecto sexual da relação amorosa. Por isso, seu discurso está, sim, sujeito à ironia veiculada por Platão no discurso de Diotima. Ver também a esse respeito a nota 24.

${ }^{45}$ Isto valeria tanto para Alcibíades quanto para Cármides, por exemplo. 
Se não se adotar a interpretação aqui proposta, resta ao intérprete dos diálogos um conjunto de afirmações dificilmente harmonizáveis. Por um lado, algumas passagens indicariam que Sócrates dava valor à beleza física dos jovens e por esse motivo sentia-se atraído por eles; por outro lado, há passagens que indicariam exatamente o contrário. Ora, por mais que as figuras contraditórias possam agradar à sensibilidade contemporânea, esse não parece ser o caso da personagem construída com maestria por Platão.

Um dos fatores que pode levar à opinião, errônea, de que a beleza física dos jovens que "caça" seja importante em alguma medida para Sócrates é a não distinção das duas dimensões do eros filosófico. Só no que diz respeito à primeira dimensão, nomeadamente, o desejo pelo mais alto conhecimento, pode a beleza física ter um papel relevante, já que ela é o elemento desencadeador da ascensão em direção à Forma da Beleza, de acordo com o Banquete. Posto isso, há possivelmente uma supervalorização da importância da beleza física para Platão.

As causas de tal supervalorização podem residir na projeção, ao interpretar os diálogos, da importância de que a beleza física gozava própria cultura grega como um todo, ou ainda numa leitura equivocada do Banquete: pelo fato de a "escada do amor" começar com o amor dum belo corpo, supõe-se que a erótica ascensional do dialético (que é o que no fundo está em jogo na "escada do amor") dependa necessariamente de algo fisicamente belo como elemento desencadeador. Entretanto, mesmo que a Forma da Beleza tenha um lugar de destaque na metafísica platônica, principalmente se se puder identificá-la com a Forma do Bem, tema que não poderei abordar aqui, nem toda ascensão erótica tem de necessariamente começar com uma instância sensível do belo, assim como a ascensão dialética na direção da Forma do Bem não começa necessariamente pelas coisas boas do mundo sensível, embora seja a Ideia de Bem o termo de toda dialética.

Não há, portanto, motivo para vincular a erótica platônica à beleza corpórea. A erótica platônica é sempre dialética e qualquer busca dialética, começando ou não pela beleza, será erótica. Eros, entendido como eros filosófico, desejo e mola propulsora da busca do conhecimento das Formas, não é, de resto, um termo exclusivo do Banquete ${ }^{46}$. Querer fundar uma "erótica" platônica, aplicável ou não a Sócrates, que dependa necessariamente da beleza física como elemento desencadeador seria perder de vista que a beleza física não é nem sequer a única realidade sensível capaz de despertar o eros filosófico, embora se deva admitir sua preeminência nesse respeito ${ }^{47}$. O que é mais relevante na "escada do amor" é que a beleza física é o elemento disparador da abordagem dialética, a qual pergunta pelo elemento uno que unifica as múltiplas manifestações do belo físico. Porém,

${ }^{46}$ A relação de eros ou do desejo com o percurso filosófico fica mais do que clara no Fedro, mas também na República e no Fédon. Ver Pl. Phd. 68a-b, 65c9, 66b7, 66e2-3 67b9. Ver também: P1. Resp. 464c8-475c; 490b. Passagens de Fédon e República compiladas por Kahn 1996: 274-275.

${ }^{47}$ Sobre esse ponto ver a longa passagem do Fedro citada infra. 
como fica claro, por exemplo, no Fedro, o elemento disparador do processo poderia muito bem não ser a beleza sensível, mas sim as manifestações sensíveis da temperança, justiça ou sabedoria ${ }^{48}$.

Outro fator que pode conduzir a erro nessa questão do papel da beleza física para Platão é, como já foi mencionado, a sua importância para os ideais gregos de arete e de kalokagathia. Contudo, é preciso estar atento para o fato de que Platão representa não uma continuidade, mas sim uma ruptura com muitos dos valores de seu tempo ${ }^{49}$, inclusive com os conceitos de arete e de kalokagathia.

Ora, se é certo que o que está sempre em jogo na questão da pederastia é um ideal de arete, também é certo que este é um ponto sobre o qual o Sócrates dos diálogos sempre se mostrou subversivo, desde a própria Apologia e dos chamados diálogos de juventude. Nesses textos, principalmente quando lidos em conjunto, já fica indicado que Platão deseja estabelecer uma nova concepção de arete como sophia, e num sentido forte e inédito: episteme $e^{50}$ ou conhecimento fundamentado, para o qual a beleza física dos envolvidos não conta nem minimamente. Por outro lado, ainda que o ideal grego de kalokagatbia incluísse a beleza física, também esse ideal está sujeito à revisão platônica. Na República, aliás, Sócrates chega a ironizar a concepção tradicional de kalokagathia ${ }^{51}$.

Fazer todos os ajustes necessários para evitar que a falsa crença da importância da beleza física para Platão comprometa a reta compreensão de sua "erótica" não implica, como pode parecer à primeira vista, em aniquilá-la, pois é a própria via dialética, tão vital para Platão, que é sempre erótica, qualquer que seja seu ponto de partida; o erro estaria em querer, a todo custo, que a via erótico/ dialética começasse sempre com uma instância do belo sensível.

${ }^{48}$ Ver também a longa passagem do Fedro citada a seguir no corpo do texto (Pl. Phdr. 250a-d; Nunes 2007b: 76-77), com destaque especial para os seguintes trechos: [...] Porém não sabem o que se passa com elas, por carecerem de percepção bastante clara, pois em relação à justiça, à temperança e tudo o mais que a alma tem em grande estima, as imagens terrenas são totalmente privadas de brilho; com órgãos turvos e, por isso mesmo, com assaz dificuldade, é que as poucas pessoas que se aproximam das imagens conseguem reconhecer nelas o gênero do modelo original [...]; [...] contudo não percebe a sabedoria, pois esta despertaria em nós violenta paixão se apresentasse a nossos olhos uma imagem tão clara como a da Beleza [...]. Em suma, a temperança, a justiça e a sabedoria seriam poderosíssimos desencadeadores de eros caso fossem tão visíveis quanto a beleza na viagem das almas pelo hiperurânio.

${ }_{49}$ Basta mencionar as propostas da República no que concerne às restrições à poesia tradicional, à educação das mulheres e, principalmente, à comunidade universal de mulheres, filhos e bens.

${ }^{50}$ Ver Motta 2006.

${ }^{51}$ Note-se que nessa obra Platão faz Sócrates dirigir uma sutil ironia ao uso superficial, segundo seus novos critérios, do termo kalos k'agathos: [...] dos ricos e dos chamados homens de bem [kalon k'agathon]. Cf. Pl. Resp. 569a3-4; Pereira 1987: 406. E se o faz é porque tem uma concepção bem diferente da tradicional sobre o que deva ser alguém que mereça essa qualificação. Sobre esse ponto ver: Motta 2010. 
Assim como não é preciso negar a "erótica" platônica, também se pode preservar certo tipo de "pederastia" platônica, aquela existente na relação mestre-discípulo, podendo estes até serem chamados de amante e amado. Contudo, tanto o sentido de eros quanto o de pederastia tem de sofrer significativas inflexões.

Assim sendo, a personagem de Sócrates, amante de belos jovens, faz parte de uma genial estratégia de apropriação, por parte de Platão, das relações pederásticas de seu tempo, bem como do próprio termo eros, apropriação essa que tem seu ápice no Banquete, embora possa ser mais bem compreendida com o concurso de outros diálogos, principalmente do Fedro e da República. E essa apropriação é tão genial no Banquete porque prevê a continuidade literária entre o discurso de Sócrates/Diotima e os discursos anteriores, nos quais a pederastia tradicional é sempre tema de destaque. É por isso que é possível ver Diotima referir-se à pederastia e mesmo considerar a possibilidade de que a "escada do amor" possa incluir o belo corpo de um jovem. É como os olhos na continuidade e na unidade literária que Platão propõe uma inflexão do vocabulário erótico, o que longe de ser uma falha que deixaria a obra confusa, apenas exige que o leitor que não fique preso ao que fora dito anteriormente sobre eros, e coloque-se sempre na postura ativa de intérprete, como parecer querer o autor dos diálogos.

Sendo assim, que a beleza de um corpo possa estar no começo da "escada do amor", e que possa até ser a beleza física de um jovem, não exclui que a ascensão descrita pudesse começar igualmente pelo questionar o que torna belos todos os belos cavalos. Porém, mesmo supondo que a beleza de um belo jovem esteja sendo referida nessa altura, ela diria respeito apenas à primeira dimensão do eros filosófico, a saber, o desejo de possuir o conhecimento das formas, que, nesse caso, seria despertado por uma exemplificação sensível da Forma da Beleza, independentemente do fato de o "amante" sentir-se sexualmente atraído pelo "amado".

Em suma, ainda que a beleza que desperta a busca dialética pela Forma de Beleza possa ser a de um belo jovem, isso é meramente acidental; entretanto, é preciso admitir que, no contexto do Banquete, isso é literariamente desejável; e esse é motivo pelo qual Platão mantém essa possibilidade no discurso de Diotima.

No que tange à segunda dimensão do eros filosófico, nomeadamente, a urgência de transmitir a própria dynamis filosófica da qual se está "grávido(a)", já deve estar claro que essa só pode ser despertada pela beleza da alma, ou seja, no segundo degrau da "escada do amor", estágio no qual a beleza física já não conta mais nada ${ }^{52}$. Não é de surpreender que seja exatamente nessa altura que aquele que tenha sido bem guiado, ou seja, aquele que é filósofo, converta-se ele mesmo em guia ${ }^{53}$. E isso pode bem equivaler a dizer: que ele converta-se num amante de "belos jovens".

\footnotetext{
${ }^{52}$ Cf. P1. Symp. 210b-c.

${ }^{53}$ Pl. Symp. 210b-c.
} 
Tendo tudo isso em vista, segue-se que se um observador exterior, tal como o narrador do Protágoras, afirma que Sócrates "caça" Alcibíades ${ }^{54}$ e interpreta que se trate de uma relação pederástica tradicional, isso não significa que o leitor tenha de forçosamente seguir essa interpretação. Cabe a este perceber a diferença existente entre o sentido da expressão "belo jovem" para Sócrates e o sentido que a mesma tem na boca de outras personagens.

A hipótese aqui defendida, nomeadamente, que a beleza física dos jovens aos quais Sócrates pretende servir de guia em nada importa para ele, não estaria bem fundamentada se não se procurasse dar conta da passagem supracitada do Cármides, onde Sócrates supostamente sente-se sexualmente atraído pelo personagem do diálogo homônimo. A esse respeito, pode ser muito esclarecedor considerar a passagem do Fedro na qual se descrevem os efeitos da contemplação da Forma da Beleza na jornada das almas através do hiperurânio ${ }^{55}$.

Quando, à vista da beleza, a alma readquire asas e, novamente alada, debalde tenta voar, à maneira dos pássaros dirige o olhar para o céu, sem atentar absolutamente nas coisas cá de baixo, do que lhe vem ser acoimada de maníaca. Porém, o que eu digo é que essa é a melhor modalidade de possessão, a de mais nobre origem, tanto em que se manifesta como em quem dele a recebeu. $\mathrm{O}$ indivíduo atacado de semelhante delírio, sempre que apaixonado das coisas belas, é denominado amante. Conforme disse há pouco, toda alma de homem já contemplou naturalmente a verdadeira realidade, sem o que não teria nunca adquirido essa forma; porém não é igualmente fácil para todas, à vista das coisas terrenas, recordar-se das celestes, o que se dá tanto com as que as perceberam de corrida como com as que tiveram a infelicidade de cometer alguma injustiça por influência de más companhias e de esquecer os mistérios sagrados contemplados naquela ocasião. Assim, são bem poucas as que conservam a lembrança do que viram. Sempre que essas poucas percebem alguma imagem das coisas lá do alto, ficam tomadas de entusiasmo e perdem o domínio de si mesmas. Porém não sabem o que se passa com elas, por carecerem de percepção bastante clara, pois em relação à justiça, à temperança e tudo o mais que a alma tem em grande estima, as imagens terrenas são totalmente privadas de brilho; com órgãos turvos e, por isso mesmo, com assaz dificuldade, é que as poucas pessoas que se aproximam das imagens conseguem reconhecer nelas o gênero do modelo original. Porém, a Beleza era muito fácil de ver por causa do seu brilho peculiar, quando, no séquito de Zeus, tomando parte no coro dos bem aventurados e os demais no de outra divindade, gozávamos

\footnotetext{
${ }^{54}$ Cf. P1. Prot. 309a.

${ }^{55}$ Cf. P1. Phdr. 246d-248c. Nunes 2007b: 71-73.
} 
do espetáculo dessa visão admirável e, iniciados nesse mistério que, com toda a justiça, pode ser denominado sacratíssimo, e que celebrávamos na plenitude da perfeição e livres dos males que nos alcançam no futuro, fomos admitidos a contemplar sob a luz mais pura aparições perfeitas, simples, imutáveis, puros também e libertos desse cárcere de morte que com o nome de corpo carregamos conosco e no qual estamos aprisionados como a ostra em sua casca.Basta de recordações; a pungente saudade do passado levou-nos a essas divagações. Voltemos para a Beleza. Conforme ficou dito, vimo-la refulgir entre aquelas realidades e, de volta para a terra apreendemo-la em todo o seu resplendor por meio do nosso mais brilhante sentido. A vista é, realmente, o mais sutil dos órgãos do corpo; contudo não percebe a sabedoria, pois esta despertaria em nós violenta paixão se apresentasse a nossos olhos uma imagem tão clara como a da Beleza, o que também é válido para todas as essências dignas do nosso amor. Somente a Beleza recebeu o privilégio de ser a um tempo encantadora e de brilho incomparável. Porém quem não foi iniciado de pouco ou já se corrompeu, de maravilha conseguirá alçar-se até a Beleza absoluta, sempre que contemplar aqui embaixo uma imagem com seu nome. Por isso mesmo, em vez de venerá-la quando a encontra, deixa-se dominar pelo prazer e, procedendo como um verdadeiro animal, procura maculá-la e engravidá-la, sem nada temer no seu atrevimento nem correr-se de desejar um prazer contra a natureza. $\mathrm{O}$ iniciado de pouco, pelo contrário, que tantas coisas belas já contemplou no céu, quando percebe alguma feição de aspecto divino, feliz imitação da Beleza, ou nalgum corpo a sua forma ideal, de início sente calafrios, por notar que no seu íntimo entram de agitar-se antigos temores. De seguida, fixando a vista no objeto, venera-o como a uma divindade, e se não temesse passar por louco varrido ofereceria sacrifícios ao seu amado, como o faria a uma imagem sagrada ou a algum dos deuses. A sua vista é acometido de todo o cortejo dos calafrios: muda de cor, transpira e sente um calor inusitado. Apenas recebe por intermédio dos olhos eflúvios da Beleza, irrigam-se the as asas e ele volta a inflamar-se. Como o aquecimento derrete-se o invólucro dos germes das asas, que endurecido havia muito pela secura, os impedia de brotar, e com o afluxo do alimento entumece a haste da asa e tende a lançar raízes por todo o interior da alma, pois antes a alma era recoberta de plumas.

Então tudo na alma é ebulição e efervescência, sentindo ela o mal-estar de quando apontam os dentes: sensação de gastura e irritação das gengivas. É o que se passa com a alma, quando as asas começam a criar penugem: em toda aquela efervescência, tem a impressão estranha de prurido, quando lhe nascem as asas. Assim, ao contemplar a beleza de um jovem, que emite partículas para o seu lado em moção irresistível, - daí o nome Emoção - e as recebe no seu íntimo, estas a banham e aquecem, a dor para e ela se alegra ${ }^{56}$.

${ }^{56}$ P1. Phdr. 249d-251c. Nunes 2007b: 75-76. Essa passagem, de resto, também é bastante esclarecedora sobre o ponto abordado acima: o de que a beleza sensível não é a única instância capaz de despertar eros, embora seja a que o desperte mais facilmente. Cf. supra, nota 48. 
Por ser a Forma de Beleza aquela que se contempla mais nitidamente nessa viagem, a beleza percebida nas coisas sensíveis, as quais participam da Forma da Beleza, desperta mais facilmente a lembrança de tal contemplação. Sendo assim, a passagem do Cármides poderia bem representar um exemplo de eros filosófico atuando de dois modos. Se o belo corpo de Cármides desperta em Sócrates eros, trata-se de eros filosófico, o qual denota o reconhecimento dum exemplar de beleza cuja causa é a própria Forma de Beleza. De fato, a passagem do Fedro não deixa dúvida sobre o poder "erótico" que tem sobre um iniciado a aparição duma manifestação sensível da Beleza, e a própria linguagem aqui utilizada assemelha-se muito à linguagem do trecho do Cármides em tela.

Ademais, todo o contexto de seu encontro com Cármides propicia que Sócrates, "grávido" da virtude epistémica e ávido por "fecundar", acredite estar diante de terreno fértil para essa "fecundação": de fato, antes mesmo de encontrar o rapaz, Sócrates ouve muitos elogios acerca de seu caráter e inteligência. Sendo assim, a segunda dimensão de eros filosófico, o desejo de "fecundar", também seria despertada. Se essas duas dimensões do eros filosófico atuam simultaneamente em Sócrates em seu encontro com Cármides, sua reação à vista do corpo do jovem bem poderia bem simbolizar o momento em que o filósofo é tomado de desejo a ponto de perder quase o controle.

Note-se que assim como no Cármides, também na passagem do Fedro há um belo jovem que aparece diante de um iniciado. Note-se que o aparecimento desse "belo jovem" tem o poder de aliviar a "dor" do iniciado, dor que é efeito do desejo ao qual falta o objeto. A urgência de fecundar daquele que é fecundo na alma, descrita no Banquete, também mobiliza eros filosófico, sendo mais do que verossímil, por todo o contexto, que o mesmo também seja mobilizado na passagem do Cármides.

Se Sócrates fez o percurso filosófico, então ele adquiriu também o eros filosófico, em suas duas dimensões: em primeiro lugar, a capacidade de reconhecer a existência e o valor dos mais altos objetos do conhecimento, as Formas, e, consequentemente, a capacidade de desejá-las; em segundo lugar, a urgência de transmitir essa mesma capacidade àqueles que considera terreno fértil, urgência essa, de resto, típica de qualquer fecundo, seja no corpo ou na alma.

É claro que tal interpretação da referida passagem do Cármides perderá força se se vacilar em considerar o Sócrates dos diálogos (e não necessariamente o Sócrates histórico) um homem extraordinário, completamente atípico, um homem que se submeteu a uma radical conversão. Qualquer que seja o caso, não resta dúvida de que Sócrates seja um homem animado por eros, tanto como filósofo quanto como guia de belos jovens. É preciso, no entanto, buscar compreender a natureza desse erotismo se se deseja entender essa personagem tão cuidadosamente construída por Platão. 


\section{REFERÊNCIAS BIBLIOGRÁFICAS}

Alieva, O. (2016) "Eros protrepon: philosophy and seduction in the Symposium", in Tulli, M. \& Erler, M. (Eds.), Selected papers from the tenth Symposium Platonicum. Sankt Augustin, 132-139.

Bailly, A. (2000, 4a ed.), Le Grand Bailly: Dictionnaire grec-français. Édition revue par L. Séchan et P. Chantraine. Paris.

Blondell, R. (2006), "Where is Socrates on the "Ladder of Love"?", in J. H. Lesher, D. Nails \& F. C. Sheffield (Eds.), Plato's Symposium. Issues in Interpretation and Reception. Cambridge,147-178.

Brisson, L. (2006), “Agathon, Pausanias, and Diotima in Plato's Symposium: paiderastia and philosophia", in J. H. Lesher, D. Nails \& F. C. Sheffield (Eds.), Plato's Symposium. Issues in Interpretation and Reception. Cambridge, 229-251.

Bury, R. G. (2010), The Symposium of Plato. London.

Corrigan, K.; Corrigan, E. G. (2006), Plato's Dialectic at Play: Argument, Structure, and Myth in the Symposium. Pennsylvania.

Dover, K. J. (1994), Greek Popular Morality in the Time of Plato and Aristotle. Indiana.

Iglésias, M. (Trad.) (2001), Mênon. Texto estabelecido e anotado por John Burnet. Rio de Janeiro.

Kahn, C. (1996), Plato and the Socratic Dialogue. The Philosophical Use of a Literary Form. Cambridge.

Kahn, C. (1987), "Plato's theory of desire", The Review of Metaphysics 41: 77-103.

Liddell, H. G.; Scott, R. (1940, 9a ed.), Liddell and Scott Greek-English Lexicon. Oxford.

Motta, G. D. (2010), A educação como fundamento da unidade e da felicidade da pólis na República de Platão. 293f. Tese (Doutorado em Filosofia), Universidade Federal do Rio de Janeiro, Instituto de Filosofia e Ciências Sociais. Rio de Janeiro.

Motta, G. D. (2014), "Educação, costumes e leis como bases para a promoção das virtudes cívicas no Protágoras e na República", Archai 12: 107-115.

Motta, G. D. (2006), "Elementos para uma antropologia filosófica na Apologia de Sócrates, de Platão", Coletânea 10: 159-174.

Motta, G. D. (2013), "Eros as a quality of the rational element of the soul", Proceedings I - X SYMPOSIUM PLATONICUM - THE SYMPOSIUM, 2013. Pisa, 62-65.

Nunes, C. A. (Trad.) (2001a, 2a ed.), O Banquete, Apologia de Sócrates. Belém.

Nunes, C. A. (Trad.) (2007a, 2a ed.), Critão, Menão, Hipias Maior e outros. Belém. 
Nunes, C. A. (Trad.) (2007b, $2^{a}$ ed.), Fedro, Cartas, O Primeiro Alcibiades. Belém.

Nunes, C. A. (Trad.) (2002, 2a ed.), Protágoras, Górgias, Fédon. Belém.

Nunes, C. A. (Trad.). (2001b, $3^{a}$ ed.), Teeteto, Crátilo. Belém.

Pereira, M. H. R. (Trad.) (1987, 11ª ed.), A República. Com introdução e notas. Lisboa.

Plato (1903), Platonis Opera. Recognovit brevique adnotatione critica instruxit Ioannes Burnet. Oxford. 